\title{
Stock Friend's Concept as A Strategy in Poverty Alleviation: A Case of Ngomeni Community of Mwingi North Sub County Kitui County in Kenya
}

\author{
Kiambi G M'mboroki', Patrick W Watete ${ }^{2 *}$ \\ ${ }^{1}$ Ministry of Livestock Development, Kanyakine, Kenya \\ ${ }^{2}$ Ministry of Livestock Development, Nairobi, Kenya
}

"Corresponding author: Patrick W Watete, Ministry of Livestock Development, Box 34188 Nairobi, Kenya. Email: pwatete@ gmail.com

Citation: M'mboroki KG, Watete PW (2017) Stock Friend's Concept as A Strategy in Poverty Alleviation: A Case of Ngomeni Community of Mwingi North Sub County Kitui County in Kenya. Arch Vet Sci Technol: AVST-132. DOI:10.29011/AVST-132/100032

Received Date: 18 August, 2017; Accepted Date: 30 August, 2017; Published Date: 07 September, 2017

\begin{abstract}
One of the challenges facing Kenya is high levels of poverty. Different ways of poverty alleviation have been tried, including stock friend's strategy. "Stock friends" strategy is the loaning and sharing of animals or herds as a survival strategy and is also used for building social contacts and bonds within the group or community. This study investigated the influence of awareness of the existence of stock friend's concept in poverty alleviation in Ngomeni division, Mwingi district. The study involved a socio-ecological survey of 233 households sampled and complemented by key informant interviews. Data was analysed using SPSS version 20. Participation of individuals in the stock exchange strategy was influenced by awareness of the givers and receivers about the importance of stock friendship strategy. As awareness increased, participation of the individuals also increased. Community awareness of existence of stock exchange strategy and the consequent adoption of the strategy influenced community's poverty levels. There is therefore need to inform the community about the importance of stock exchange strategy to promote the uptake of the strategy.
\end{abstract}

Keywords: Adoption; Food security; Livestock exchange; Pastoralism; Safety Nets

\section{Introduction}

Today one of the challenges the world is facing is high levels of poverty among its populations, of which Kenya is not an exception [1]. Different ways of poverty alleviation are applied ranging from political, economic, socio-economic and socio-cultural. One such socio-cultural way is the "Stock Friends" strategy, very common and popular among pastoralists and agro-pastoralists. Pastoral and agro-pastoral people live in unpredictably harsh and varying environments [2], and initiate exchange of livestock among themselves for reasons of security. Socio-culturally, herders exchange livestock in return for social capital and symbolic capital. Both forms of capital may be put to use in times of need as herds can be lost and or decrease rapidly in bad seasons, or in an epidemic or a raid. One of a number of strategies that pastoralists and agro-pastoralists use to combat and alleviate poverty is based on the "Stock Friends" concept. "Stock Friends" strategy is the loaning and shar- ing of animals or herds as a survival strategy (Safety net) [3]. It is also used for building social contacts and bonds within the group or community. Such relationships are built with friends spread widely as a safety mechanism to ensure survival of some stock in time of catastrophe in own location. It is also used as a means of improving breeds and providing immediate subsistence to those in need. Livestock acquisitions through forms of exchange can entail the trading of livestock, daily food sharing, begging, or ceremonial food sharing at feasts, such as weddings. Livestock exchange plays a role in acquisition (additions) of livestock to the herd and that the exchange is driven by social ties and networks of which Livestock or herding partnerships ("Stock Associates") are part of this network, and are established by birth and deliberate pledges between bond friends [4]. Among the Turkana, social networks are dense such that many friends are themselves friends with each other, and social relationships vary according to degrees of friendliness [5]. People in active relationships share food, exchange livestock, and engage in mutual labour and leisure. The size of a herder's social network influences his herding success [6]. 


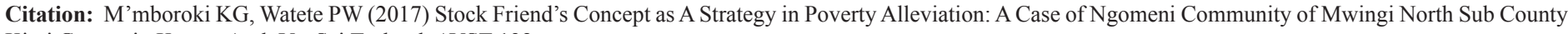
Kitui County in Kenya. Arch Vet Sci Technol: AVST-132.

Despite this general centrality of social relationships and their role in livestock acquisitions, the importance of socially induced livestock exchanges to herd growth has with few exceptions remained largely unrecognized and seldom quantified [7]. Although the stock friend's strategy has been practised by some agro-pastoralists of Ngomeni in Mwingi, its impact on poverty levels and alleviation has not been obvious or clearly understood by development proponents and the communities alike. What has been assumed, however, is that communities' general awareness of the stock-friend's strategy, and their ability to offer livestock for exchange to the needy, are necessary conditions for the adoption of the strategy.

Although the "Stock Friends" strategy is known to have benefited pastoralists and agro-pastoralists in many parts of Kenya by reducing poverty and attenuation of its agonizing impacts, through exchange of livestock and products, the strategy has not been as beneficial among the Ngomeni community of Mwingi District [8]. But more commonly postulated is their seemingly inadequate or lack of awareness and knowledge of the concept, which seems to have been neglected, and has thus faded away, eroding the interest of the communities.

The broad objective of the study was to investigate the influence of awareness of the existence of stock friend's concept in poverty alleviation in Ngomeni division, Mwingi district, through the assessment of communities' awareness and understanding of the strategy and its processes, and their adoption of the strategy, which is expected to influence poverty alleviation among the communities.

\section{Materials and Methods}

The study was conducted in Ngomeni Division, which is one of the nine Divisions of Mwingi District in Eastern Province of Kenya. The District lies between latitude $0^{\circ} 0^{\prime}$ and $1^{\circ} 12^{\prime}$ south and longitude $37^{\circ} 47^{\prime}$ and $38^{\circ} 57^{\prime}$ degrees east, and has an area of $10,030.30 \mathrm{~km} 2$, [9]. As indicated in the map of the study area, Figure 1, Ngomeni Division is in kitui county mwingi sub county and comprised of two Locations, namely Mitamisyi and Ngomeni locations (with each of the two locations having four sub-Locations). Ngomeni Division borders Nguni Division to the south, Kyuso Division to the west, Tseikuru Division to the north, and Tana River District to the east.

Currently, Mwingi District being in Kitui County is made of three sub-counties, namely Mwingi North where Kyuso District and Ngomeni Division belongs, Mwingi Central and Mwingi West. Topographically Ngomeni Division is generally plain with a few sandy rocky hills. The landscape is generally flat, with a plain that gently rolls down towards the east where altitudes are as low as $400 \mathrm{~m}$. Topography of the Division affects communication within the Division and with other Divisions. Ngomeni experience severe droughts, which has led to livestock deaths, food shortages and poverty. The Division has red sandy soils of moderate to sometimes-low fertility and prone to erosion.

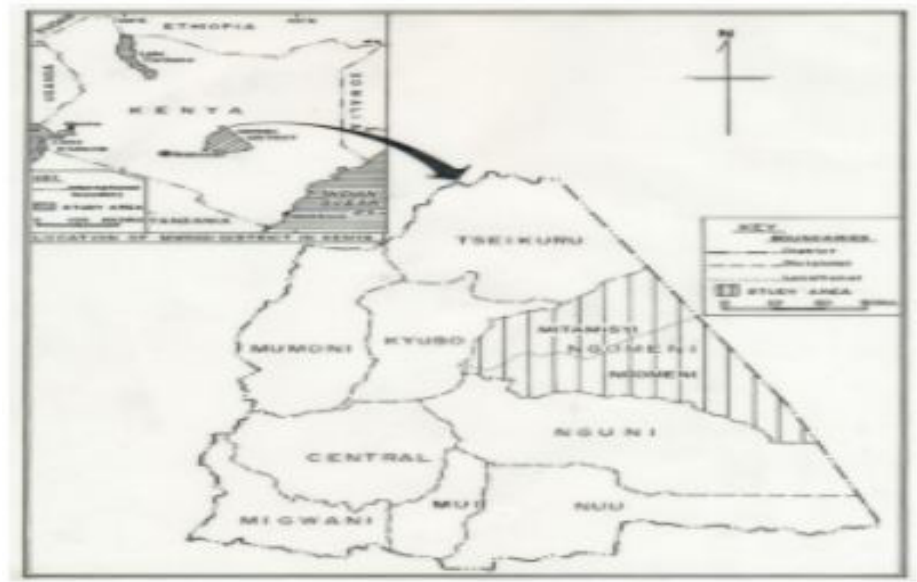

Figure 1: Location of Ngomeni Division in Mwingi District. Source [10].

Climate of the Division is hot and dry for the larger part of the year. The maximum mean annual temperature ranges between $26^{\circ} \mathrm{C}$ and $34^{\circ} \mathrm{C}$. while the minimum mean annual temperatures vary between $14^{\circ} \mathrm{C}$ and $22^{\circ} \mathrm{C}$. with an average annual temperature is $24^{\circ} \mathrm{C}$. The Division has two rainy seasons; March-May (long rains) and October- December (short rains). Rainfall ranges between $400 \mathrm{~mm}$ and $800 \mathrm{~mm}$ per year, but is erratic. The short rains are more reliable than the long rains [11]. This rainfall pattern is characteristic of arid and semi-arid climate, in which livestock rearing is a dominant occupation of the agro-pastoral communities, and where stock friend strategy is instrumental to poverty mitigation.

The study utilised a socio-ecological survey using a structured questionnaire, and supported by Key Informant interview and observation (ocular) methods. The research also made use of secondary data from relevant sources. The study population was comprised of 2,165 households in Ngomeni Division, while the Sampling Frame was constituted by all the households keeping livestock in four sub-locations randomly selected from two locations of the Division. The unit of analysis was the household and the subject of analysis (the respondent) was the head of the household or his or her representative. Random sampling was undertaken among the systematically selected households in each sub-location, to constitute a study sample of 240 households, with 60 households randomly selected from the each of the four sublocations.

The study population is distributed in Ngomeni division of Mwingi North Sub County. The Division has two locations, namely, Ngomeni and Mitamisyi, and eight sub-locations, four in Ngomeni (Kavuti, Kalwa, Kabauni and Ikime), and the other four in Mitamisyi (Ndatani, Mitamisyi, kamusiliu and kimera). 


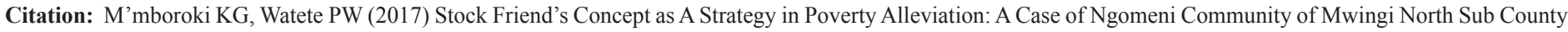
Kitui County in Kenya. Arch Vet Sci Technol: AVST-132.

The study covered four sub-locations of Ngomeni Division, namely Kavuti and Kalwa sub-locations (of Ngomeni location), and Mitamisyi and Ndatani sub-locations (of Mitamisyi location) as indicated in (Table 1).

\begin{tabular}{|c|c|c|c|c|}
\hline Division & Location & $\begin{array}{c}\text { Sub-loca- } \\
\text { tion }\end{array}$ & Frequency & Percent \\
\hline \multirow{3}{*}{ Ngomeni } & Ngomeni & Kavuti & 59 & 25.3 \\
\cline { 2 - 5 } & & Kalwa & 57 & 24.5 \\
\cline { 2 - 5 } & Mitamisyi & Mitamisyi & 58 & 24.9 \\
\cline { 2 - 5 } & & Ndatani & 59 & 25.3 \\
\hline
\end{tabular}

Table 1: Distribution of respondents.

The questionnaires were distributed as follows: Kavuti 59, Ndatani 59, Mitamisyi 58, and Kalwa 57, totalling to a study sample of 233 respondent households that provided a fair representation of the communities involved in the study.

\section{Data Analysis}

The computer-based Statistical Package for the Social Sciences (SPSS) programme was used for the analysis. All the variables in the hypotheses statements (which are the same as those in the specific objectives) were constructed into indexes from 5 to 6 relevant indicator variables. Each of these indicator variables was scored on Likert scale measures, ranging from a score of 0 where a condition is non-existent, to 5 or 6 where the condition is at highest level. The indicator variable was then summed up to construct the index variables, generating continuous variables as a result, (with scores ranging from 0 to 25 or 30 ), warranting the use of regression analysis to determine relationships between them

\section{Results}

\section{Respondent's characteristics and land use}

The average family size was 6 members and worked on their agro-pastoral land of 10 acres on average. Mostly cattle, goats and donkeys were reared for transportation of goods.

\section{The Community's awareness of the existence of the stock friend strategy amongst them}

Ngomeni respondent agro-pastoralists were asked to indicate their awareness of the stock friend concept and strategy, and a very large majority $(91.8 \%)$ responded to the affirmative (Table 2).

\begin{tabular}{|c|c|c|}
\hline Awareness & Frequency & Percent \\
\hline Yes & 214 & 91.8 \\
\hline No & 19 & 8.2 \\
\hline
\end{tabular}

Table 2: Respondents' awareness of stock friend's concept and Strategy among Ngomeni community.

Asked how common the strategy was among the Ngomeni community, $57.5 \%$ of them thought that it was common to very common, while $42.5 \%$ said it was rare to very rare (Table 3 ).

\begin{tabular}{|c|c|c|}
\hline Awareness & Frequency & Percent \\
\hline Very common & 31 & 13.3 \\
\hline Common & 103 & 44.2 \\
\hline Rare & 78 & 33.5 \\
\hline Very rare & 21 & 9.0 \\
\hline
\end{tabular}

Table 3: Respondents' awareness of how common the strategy was in Ngomeni.

\section{Degree of awareness of some aspects of the exchange strategy}

The respondents were asked to assess the degree of their awareness of various aspects in the stock exchange strategy, as listed in (Table 4) The highest degree of awareness was of the procedures and processes involved in the stock exchange $(88 \%)$, followed by the awareness of the receivers of the stock $(74.2 \%)$ and the existence of the stock exchange strategy (64.3\%), since the respondents assessed the three aspects as of very high, high and moderately high degrees. The respondents were aware on various aspects in the stock exchange strategy (Stock friends) although the degree of practice (adoption of the practice) seemed lower than the degree of awareness.

\begin{tabular}{|c|c|c|c|c|c|c|}
\hline Aspect of awareness & $\begin{array}{c}\text { V.H.D } \\
(\%)\end{array}$ & $\begin{array}{c}\text { H.D } \\
(\%)\end{array}$ & $\begin{array}{c}\text { M.D } \\
(\%)\end{array}$ & $\begin{array}{c}\text { L.D } \\
(\%)\end{array}$ & $\begin{array}{c}\text { V.L.D } \\
(\%)\end{array}$ & $\begin{array}{c}\text { N.A } \\
(\%)\end{array}$ \\
\hline The existence of the stock exchange strategy & 6.0 & 25.3 & 33.0 & 28.3 & 4.4 & 3.0 \\
\hline Of the receivers of the stock exchange strategy & 3.0 & 30.0 & 41.2 & 19.4 & 3.4 & 3.0 \\
\hline Of the givers of the stock exchange strategy & 3.9 & 28.8 & 21 & 41.2 & 2.5 & 2.6 \\
\hline Of the reasons for giving the stock & 7.3 & 21.5 & 39.9 & 25.3 & 3.4 & 2.6 \\
\hline $\begin{array}{l}\text { Of the procedures and processes involved in the stock } \\
\text { exchange }\end{array}$ & 15.9 & 43.3 & 28.8 & 6.0 & 2.6 \\
\hline
\end{tabular}

Table 4: Degree of awareness of the aspects of the exchange strategy. 
Citation: M'mboroki KG, Watete PW (2017) Stock Friend's Concept as A Strategy in Poverty Alleviation: A Case of Ngomeni Community of Mwingi North Sub County Kitui County in Kenya. Arch Vet Sci Technol: AVST-132.

\section{Relationship between various aspects of awareness and participation in stock exchange relationship}

Awareness of the various aspects of stock friendship tended to encourage participation in the practice. This influence was significant $(\mathrm{p}<0.001)$. Receivers and givers participated more when their awareness was high. Individuals who were more aware about the reasons for participating in stock exchange relationships tended to participate more than those who had low awareness (Figure 1).

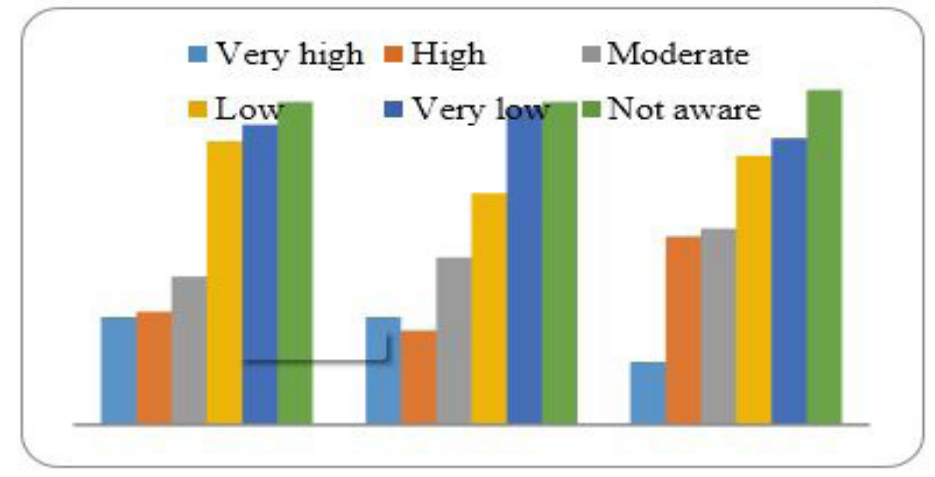

Figure 1: Relationship between various aspects of awareness and participation in stock exchange relationship.

The relationship between community awareness of existence of stock exchange strategy and their adoption of the strategy.

As indicated in (Table 5), there is a statistical significant relationship between community awareness of existence of stock exchange strategy, and their adoption of the strategy and so their poverty levels.

The $\beta$ (Beta) statistics which are the measures of association between the variables, are statistically significant and are large (with- 0433 and-0.314 values respectively), suggesting a strong relationship between the community awareness of the strategy, their adoption of the strategy, and poverty levels.

Moreover, the coefficient of determination, R square (R2) is also large and statistically significant, implying that the two independent variables explain $23.8 \%$ variation in the dependent variable, poverty levels.

\begin{tabular}{|c|c|c|c|c|c|c|}
\hline & Model & $\begin{array}{r}\text { Unstan } \\
\text { Coef }\end{array}$ & $\begin{array}{l}\text { ardized } \\
\text { ients }\end{array}$ & $\begin{array}{c}\text { Standardized } \\
\text { Coefficients }\end{array}$ & t & $\mathrm{Sio}$ \\
\hline & & B & $\begin{array}{l}\text { Std. } \\
\text { Error }\end{array}$ & Beta & & \\
\hline & (Constant) & 34.920 & 1.301 & & 26.831 & .000 \\
\hline 1 & $\begin{array}{c}\text { Community } \\
\text { adoption of stock } \\
\text { exchange strategy }\end{array}$ & -.109 & .020 & -.314 & -5.370 & .000 \\
\hline & $\begin{array}{c}\text { Degree of } \\
\text { Awareness of } \\
\text { Stock Exchange } \\
\text { strategy }\end{array}$ & -.432 & .058 & -.433 & -7.406 & .000 \\
\hline & & & & & & \\
\hline
\end{tabular}

Table 5: Regression Coefficients (degree of awareness and adoption).

\begin{tabular}{|c|c|c|c|}
\hline Model & $\mathrm{R}$ & R Square & Sig. F Change \\
\hline 1 & $.488 \mathrm{a}$ & .238 & .000 \\
\hline
\end{tabular}

Table: 5.1: Dependent variable: Poverty level.

The negative $\beta$ statistics imply that the higher the degree of stock exchange strategy awareness and the higher the levels of adoption of the strategy, and the lower will be the poverty levels.

\section{Discussion}

\section{Community's awareness of the existence of stock friend}

The stock exchange was common to very common in the two out of four sub-locations of the division Kalwa and Ndatani while Kavuti and Mitamisyi was rare. This was due to proximity of the sub-locations to the town (market) where the main work was retail business. The givers normally disposed the older animals at these markets and bought others to take to the receivers for replacement. Ideally, we could have expected that the strategy could be common in faraway locations than in locations near markets centres due non-interference in their cultural practices, but it seemed that the practice had changed from cultural to economic.

A frequency distribution of the index indicated a distribution of 23 scores, ranging from a minimum 6 to a maximum 29, with an average of 20.4. A score of 20.4 from a scale of 23 amounts to $(88.7 \%)$ awareness, which was quite high. The index of respon- 
Citation: M'mboroki KG, Watete PW (2017) Stock Friend's Concept as A Strategy in Poverty Alleviation: A Case of Ngomeni Community of Mwingi North Sub County Kitui County in Kenya. Arch Vet Sci Technol: AVST-132.

dents' degree of awareness concurred with degree of awareness of some aspects of the exchange strategy and proved that the respondents were aware of the strategy and its processes and other activities under study; although adoption of stock friend's strategy was low. Thus awareness of the strategy alone may not have contributed to the fading away singly of the stock friend's strategy. As suggested by A review of the Kenya Integrated Household Budget Survey report Of (2005-2006) and quoted in 'Coping Strategies among Urban Poor: Evidence from Nairobi, Kenya' by [12] that Most common coping strategies at the national level rank is selling animals and receiving help from family and friends among others [13] concurs with this study. Therefore, awareness of selling those animals and the relationship of the family members can help in increase of adaption of the strategy thus reducing poverty.

\section{Potentiality of stock exchange strategy and its adoptabil- ity}

As indicated by key informants, and the sections of this research described above, stock exchange strategy could be made adoptable and useful to Ngomeni community to enhance poverty alleviation by considering the independent and intermediate variable so that the strategy can alleviate poverty. The key informants reported that if the educated and well up members of the community who lived in Nairobi and other towns were aware of the practice and its importance in community wellbeing and became givers, this could increase adoption and thus enhance poverty alleviation. The other information was that the animals were grazed up to maturity and replaced, thus the off take was increased and also the system triggered a market for immature cattle from other neighbouring beef producing districts [14].

As indicated by [15] the stock friend's strategy if adopted could increase the off take (numbers and types of livestock) going to market and thus reduces poverty due to increased income. Therefore, the well up of the community, after buying the immature from other counties Mwingi becomes a finishing zone for the Nairobi market.

\section{Conclusion}

As diffusion and adoption occurs over time, one individual communicates a new idea to another individual in a context of a particular social system, and this leads to either an adoption or a rejection by the second individual. If the second individual adopts, he or she will normally pass through five stages: awareness, interest, evaluation, trial, and finally, adoption. In turn, the stock friend strategy would influence alleviation and possible eradication of poverty among the Mwingi agro-pastoralists.

Therefore, participation of individuals in the stock exchange strategy was influenced by awareness of the givers and receivers about the importance of stock friendship strategy. As awareness increased, participation of the individuals also increased.
Community awareness of existence of stock exchange strategy and the consequent adoption of the strategy influenced community's poverty levels. Adoption of the strategy led to a decrease in poverty levels.

\section{Recommendations}

There is need to inform the community about the importance of stock exchange strategy. Because the practice seemed to change from cultural to economic, there is need for financial institutions and donors to introduce packages for credit and assistance respectively to promote the concept and thus address food security and alleviate poverty.

An alternative to the stock exchange strategy, based on similar model, is the provision of livestock to the poor. This should be moulded and embodied in the spirit of giving amongst the community, which should be based on local customs, and be acceptable, sustainable and viable.

\section{References}

1. Mango N, Cheng'ole J, Kariuki G, Ongadi W (2004) Quantitative Methods for Poverty Analysis. Paper presented at KIPPRA-cornell SAGA workshop, on $11^{\text {th }}$ march 2004. Grand Regency Hotel. Nairobi Kenya.

2. Bollig M (1996) Moral economy and self-interest: Kinship, friendship and exchange among the Pokot of north West Kenya. In kingship, networks, and exchange. on-Line Journal 2: 31.

3. Widstrand CG (1975) The rationale of nomad's econom., Ambio 4: 146-153.

4. Gulliver PH (1955) The Family Herds: Reutledge and Kegan Paul (International Library of Sociology and Social Reconstruction), London.

5. Johnson BR (1999) Social networks and exchange of Turkana herders of the dry savannah: Ecology and Bio Behavioural Response of Environment. Oxford University Press.

6. M'mboroki KG, Aboud AA, Rithaa JN (2015) Assessing the Influence of Knowledge of Type and Numbers of Livestock Exchanged in Stock Friends Concept as a Strategy in Poverty Alleviation; the Case of Ngomeni Community of Mwingi District in Kenya. International Journal of Emerging Trends in Science and Technology 2: 7.

7. Fratkin E, Smith K (1994) Labour, Livestock, and Land: The organisation of pastoral production. African pastoralist systems an integrated approach. ME Sharpe.

8. Government of Kenya (2002) Mwingi District Development Plan 20022008. Ministry of Finance and Planning. Government Printer, Nairobi, Kenya.

9. World Bank Poverty Reduction and Economic Management Unit, Africa Region (2008) Kenya poverty and inequality assessment 44190KE: 224.

10. Broch-Due V (1999) Remembered cattle, forgotten People: The morality of exchange and the exclusion of the Turkana Poor. James Currey Publishers. 
Citation: M'mboroki KG, Watete PW (2017) Stock Friend's Concept as A Strategy in Poverty Alleviation: A Case of Ngomeni Community of Mwingi North Sub County Kitui County in Kenya. Arch Vet Sci Technol: AVST-132.

11. Djesika DA, Steven B, Shukri M, Sassy M (2014) Coping Strategies among Urban Poor: Evidence from Nairobi, Kenya

12. Dyson HR, McCabe JT (1985) Southern Turkana nomadism: coping with a predictably varying environment 11: 12 .

13. Fratkin E (1987) Age sets, households and organizations of the pastoral productions: The Ariaal, Samburu and Rendille of Northern Kenya. Research in Economic Anthropology 8: 1-25
14. Lauer RH (1982) Perspectives on social change, Third edition by Allyn and Bacon, Inc., 470 Atlantic Avenue, Massachusetts 02210.

15. Leslie P, Dyson H (1999) People and Herds 34: 1-25. 